\title{
TRENDS IN UNICOMPARTMENTAL KNEE ARTHROPLASTY
}

\section{TENDÊNCIAS NA ARTROPLASTIA DO JOELHO UNICOMPARTIMENTAL}

\author{
AHMET NADIR AYDEMIR ${ }^{1}$ (D), MEHMET YUCENS ${ }^{1}$ (1) \\ 1. Pamukkale University, Faculty of Medicine, Department of Orthopedics and Traumatology, Denizli, Turkey.
}

\section{ABSTRACT}

Objective: To evaluate trends in publications on unicompartmental knee arthroplasty (UKA) from the past to the present. Methods: As a web-based analysis, all UKA research articles, editorial letters, case reports, reviews and meeting abstracts published on the Thomson Reuters' Web of Knowledge were evaluated. The period from the first publication in 1980 to January 2019 was divided into four decades and publications were evaluated. Research articles were grouped into headings according to the subjects. Results: A total of 1,658 publications were evaluated in this study. The most frequent term used in the publications title was "outcome," with 260 items, followed by "biomechanics and kinematics," with 99 items. Most reports have been published in the last decade, and the most common type of publication was postoperative follow-up and results. Conclusion: In parallel with technological advancements, publications related to UKA-especially patient-specific instrumentation, navigation, and robotic surgery-will increase in number and become more specific. Level of Evidence V, Expert Opinion.

Keywords: Arthroplasty, Replacement, Knee. Trends. Publications.

\section{RESUMO}

Objetivo: Avaliar as tendências de publicação da artroplastia unicompartimental do joelho do passado para o presente. Métodos: Nesta análise baseada na web, foi feita uma avaliação de todos os artigos de pesquisa de artroplastia unicompartimental do joelho, cartas editoriais, relatos de caso, resenhas e resumos de reuniões publicados na Thomson Reuters Web of Knowledge. O período da primeira publicação em 1980 a janeiro de 2019 foi dividido em quatro décadas, e as publicações foram avaliadas. Os artigos de pesquisa foram agrupados em títulos de acordo com os sujeitos. Resultados: Um total de 1.658 publicações foram avaliadas neste estudo. O termo mais utilizado no título das publicações foi "resultado", com 260 itens, seguido de "biomecânica e cinemática", com 99 itens. A maioria dos relatos foi publicada na última década, e o tipo mais comum de publicação foi visto como acompanhamento e resultados pós-operatórios. Conclusão: Em paralelo aos avanços tecnológicos, as publicações relacionadas à artroplastia unicompartimental do joelho, especialmente instrumentação personalizada, navegação e cirurgia robótica, aumentarão em número e se tornarão mais específicas. Nível de Evidência V, Opinião de Especialista.

Descritores: Artroplastia do Joelho. Tendências. Publicações.

Citation: Aydemir AN, Yucens M. Trends in unicompartmental knee arthroplasty. Acta Ortop Bras. [online]. 2020;28(1):19-21. Available from URL: http://www.scielo.br/aob.

\section{INTRODUCTION}

Osteoarthritis $(\mathrm{OA})$ is defined as a syndrome of joint pain and dysfunction caused by substantial joint degeneration. ${ }^{1}$ The epidemiology of the disorder is complex and multifactorial, with genetic, biological, and biomechanical components. ${ }^{2}$ Arthroplasty is a good treatment option in the disease advanced stages, which provides better functional outcomes than other conservative treatments. Since unicompartmental knee arthroplasty (UKA) first definition, this has become a common procedure for the treatment of single compartment osteoarthritis. UKA restores knee biomechanics with minimal bone and soft tissue damage. ${ }^{3}$ Today, UKA is an alternative to TKA (total knee arthroplasty) for single compartment osteoarthritis with the advantages of faster surgeries, less bleeding, lower costs, and faster rehabilitation. Naturally, UKA has undergone an evolutionary process, with many changes in designs, surgical techniques and indications. The influence of this evolutionary process in the literature is not surprising. Better surgical outcomes with improved technology have led to increased number of applications and subsequent literature reports. Literature reports, which were initially very few, increased exponentially. Bibliometric analysis is a method that quantitatively analyzes academic literature, mainly using citation reports and content analysis. ${ }^{4,5}$ Few bibliographic studies relate to the musculoskeletal system in the literature.

This study aimed to learn more about the UKA evolution process and to analyze its changing trends. It was a web-based analysis.

\section{MATERIALS AND METHODS}

This study was conducted on Thomson Reuters' Web of Knowledge database using the keywords "unicondylar," "UKA," "uni-condylar," "unicompartmental," and "partial knee" in the title of indexed reports,

All authors declare no potential conflict of interest related to this article.

The study was conducted at the Pamukkale University, Faculty of Medicine, Department of Orthopedics and Traumatology, Denizli, Turkey. Correspondence: Ahmet Nadir Aydemir. Kalp Merkezi 7, Çamlaraltı mahallesi, Kınıklı/Denizli, Turkey. 20070. anaydemir@yahoo.co.uk 
reviews, articles and letters from 1980-year of the first paper published in the database - to January 2019. No retrospective time constraints were set when scanning the database. All abstracts were read individually and then evaluated according to the main subject. If a publication appeared more than once when scanning with different keywords, only one evaluation was applied. Early, mid and late postoperative follow-up series were categorized under the heading of "outcome." Biomechanical or kinematic studies were evaluated under the heading of "biomechanical and kinematic"; studies on arthroplasty revision or loosening, under the heading of "revision"; studies comparing unicompartmental arthroplasty with total knee prosthesis, under the heading "U-T"; and editorial letters, answers and comments, under the heading "non-original." Case reports were evaluated under the heading "case"; review studies, under the heading "review"; navigation or computer-assisted studies, under the heading "navigation"; publications related to balancing or alignment, such as varus or valgus, under the heading "alignment"; publications focused on radiological imaging methods, under the heading "radiology"; and robotic-assisted surgery publications were evaluated under the heading "robotic." Abstracts were also evaluated according to journal, authors and date of publication. Data obtained in the study were presented graphically, using Windows Excel program. The number of publications with increasing and decreasing trends over the years were evaluated at 10-year intervals and the results were stated as graphical data rather than as a statistical evaluation.

\section{RESULTS}

A total of 1,658 publications were evaluated. The most frequent term in the titles of the publications was "outcome," with 260 items, followed by "biomechanics and kinematics," with 99 items. Figure 1 shows the graphical distribution of the top 10 publication headings. The number of publications in the last decade was higher than the total published in the first three decades. Of the last decade, 2017 was the year with the most publications $(\mathrm{n}=177)$.

Most publications came from the United States, followed by the United Kingdom, when they were evaluated according to countries. Figure 2 shows this distribution according to countries. The evaluations according to journals showed that "Journal of Arthroplasty" had the highest number of publications, followed by "Knee." The distribution of journals according to number of publications is shown in Figure 3. Publications evaluated according to the authors showed that DW Murray have made the most contributions to literature, followed by Dodd Caf. Figure 3 shows a graph with the distribution of authors by number of publications. The most cited publication was by DW Murray, with 429 citations. $^{6}$

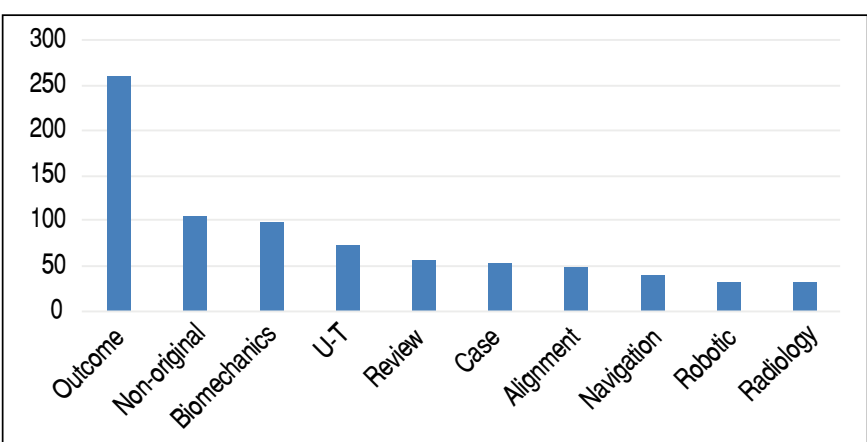

Figure 1. Graphical distribution of top 10 publication headings and numbers.

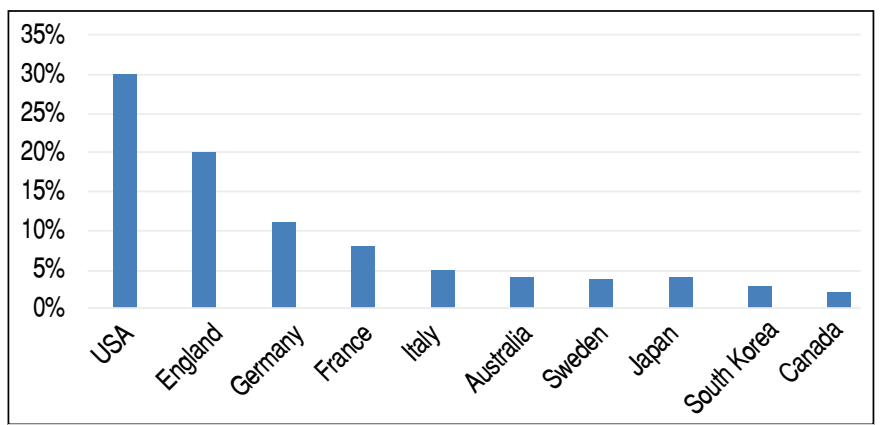

Figure 2. Graphical distribution of top 10 countries and publication percentages.

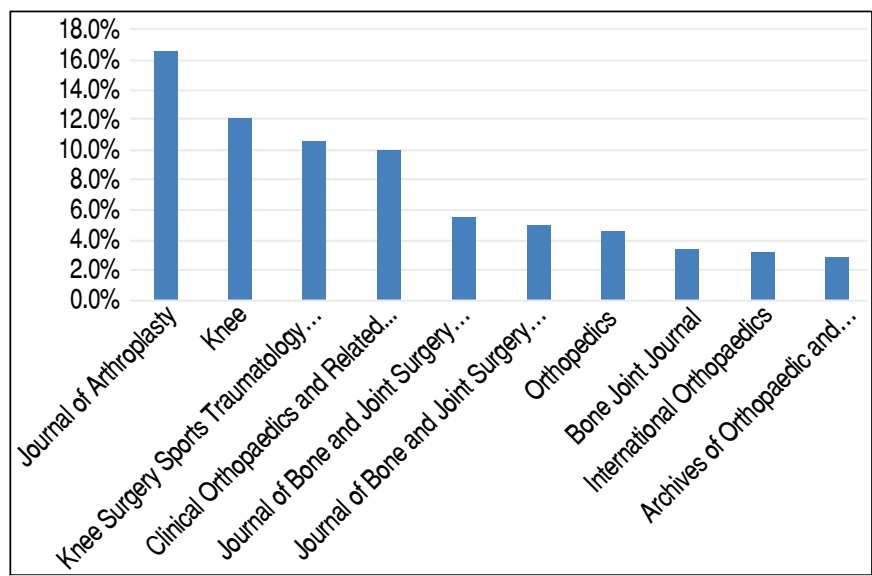

Figure 3. Graphical distribution of top 10 journals and publication percentages.

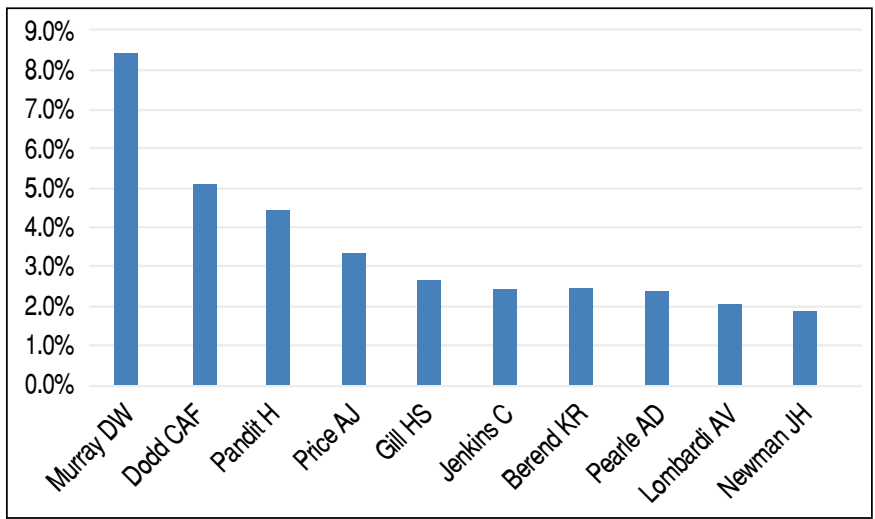

Figure 4. Graphical distribution of top 10 authors and publication percentages.

\section{DISCUSSION}

From 1980 to the date they were scanned, publications on unicompartmental knee arthroplasty have increased rapidly, especially in the last two decades. Undoubtedly, the effect of increasing patient satisfaction with developments in technology and prosthetic design is enormous. At the beginning of the 1980s, TH Mallory and J Danyi reported a revision rate of $30 \%$ in a study with an average follow-up of 5.5 years, while the revision rate in a study in 2015 with similar follow-up decreased to $7 \%$. $^{7,8}$

Studies on prosthesis design and concept are still recurrent. More than $70 \%$ of the "biomechanics and kinematics" studies carried out in this process have been published in the last decade. Among all poly-designed prosthetic studies, $87 \%$ were published in the 
last decade. In a study by D Bruni et al., ${ }^{9}$ Kaplan-Meier estimates of 8-year survival with revision for any reason as the endpoint was reported at the rate of $83 \%$. Review articles published in last decade constitute $91 \%$ of all reviews. Arguably, the accumulation of publications, and therefore the knowledge and experience on UKA, is reasonably current. The most cited review was by SC Kozinn with 276 citations. ${ }^{10}$

Surgical technique and assistive technology are also areas that changed and developed. Patient-specific instrument (PSI), navigation and robotic-assisted surgery articles have been published in the last two decades. In a 9-year mean follow-up study, navigation was compared with conventional techniques, and better coronal sequence and clinical scores were determined in the navigation group. ${ }^{11}$ In a study by Ollivier, Parratte, Lunebourg, Viehweger and Argenson, a group of patients was operated on with PSI and another group with conventional techniques..$^{12}$ After a 1-year follow-up, it was reported that PSI may confer small, if any, advantage in alignment, pain, and function after UKA. Routine use of PSI was unrecommended by the authors because of the extra cost and uncertainty related to the technique. In a prospective, randomized controlled study, robotic-assisted surgical procedures led to improved accuracy of implant positioning compared with conventional UKA surgical techniques. ${ }^{13}$ Indications also changed in UKA. Contraindications such as age, obesity, anterior cruciate ligament (ACL) deficiency are now becoming more flexible. Faour Martín, Valverde García, Martín Ferrero, Vega Castrillo, Zuil Acosta and Suárez de Puga reported $96 \%$ excellent or good results in a 12-year follow-up of a series of 51 patients (59 interventions) who underwent surgery when aged $<60 .{ }^{14}$ In another study that compared two groups according to body mass index (BMl; $<$ vs $\geq 30 \mathrm{~kg} / \mathrm{m}^{2}$ ), 10-year survival rates were reported to be similar in the two weight subgroups. ${ }^{15} \mathrm{~A}$ study of UKA in the presence of ACL deficiency showed no significant difference between the ACL intact groups at an average 5-year follow-up..$^{16}$ A recently trending approach to UKA with $A C L$ deficiency is simultaneous or subsequent ACL repair. ${ }^{17,18}$

\section{CONCLUSION}

In this study, publications from 1980 to January 2019 and trends in UKA were evaluated. Most reports have been published in the last decade, and the most common type of publication was postoperative follow-up and results. Assumingly, parallelly with advances in technology, publications related to UKA, especially $\mathrm{PSI}$, navigation, and robotic surgery will increase in number and become more specific.

AUTHORS' CONTRIBUTIONS: Each author contributed individually and significantly to the development of the manuscript. ANA: writing, performing, data analysis. MY: reviewing, language editing, intellectual concept.

\section{REFERENCES}

1. Barg A, Pagenstert GI, Hügle T, Glover M, Wiewiorski M, Henninger HB, et al Ankle osteoarthritis: Etiology, diagnostics, and classification. Foot Ankle Clin. 2013;18(3):411-26

2. Glyn-Jones S, Palmer AJR, Agricola R, Price AJ, Vincent TL, Weinans H, et al. Osteoarthritis. Lancet. 2015;386(9991):376-87.

3. Catani F, Benedetti MG, Bianchi L, Marchionni V, Giannini S, Leardini A. Muscle activity around the knee and gait performance in unicompartmental knee arthroplasty patients: A comparative study on fixed- and mobile-bearing designs. Knee Surg Sports Traumatol Arthrosc. 2012;20(6):1042-8.

4. Pekel E, Pekel G. Publication trends in corneal transplantation: a bibliometric analysis. BMC Ophthalmol. 2016;16(1):194.

5. Holden G, Rosenberg G, Barker K. Bibliometrics: A potential decision making aid in hiring, reappointment, tenure and promotion decisions. In: Holden $G$, Rosenberg G, Barker K, editors. Bibliometrics in social work. Abingdon: Routledge; 2012. p. 67-92

6. Murray DW, Goodfellow JW, O'Connor JJ. The Oxford medial unicompartmental arthroplasty: a ten-year survival study. J Bone Joint Surg Br. 1998;80(6):983-9.

7. Mallory TH, Danyi J. Unicompartmental total knee arthroplasty. A five- to nine-year follow-up study of 42 procedures. Clin Orthop Relat Res. 1983;(175):135-8.

8. Edmondson M, Atrey A, East D, Ellens N, Miles K, Goddard R, et al. Survival analysis and functional outcome of the Oxford unicompartmental knee replacement up to 11 years follow up at a District General Hospital. J Orthop. 2015;12(Suppl 1):S105-10.

9. Bruni D, Akkawi I, lacono F, Raspugli GF, Gagliardi M, Nitri M, et al. Minimum thickness of all-poly tibial component unicompartmental knee arthroplasty in patients younger than 60 years does not increase revision rate for aseptic loosening. Knee Surg Sports Traumatol Arthrosc. 2013;21(11):2462-7.

10. Kozinn SC, Scott R. Unicondylar knee arthroplasty. J Bone Joint Surg Am. 1989;71(1):145-50
11. Song EK, N M, Lee SH, Na BR, Seon JK. Comparison of outcome and survival after unicompartmental knee arthroplasty between navigation and conventional techniques with an average 9-year follow-up. J Arthroplasty. 2016;31(2):395-400.

12. Ollivier M, Parratte S, Lunebourg A, Viehweger E, Argenson JN. The John Insall Award: no functional benefit after unicompartmental knee arthroplasty performed with patient-specific instrumentation: A randomized trial. Clin Orthop Relat Res. 2016;474(1):60-8.

13. Bell SW, Anthony I, Jones B, MacLean A, Rowe P, Blyth M. Improved accuracy of component positioning with robotic-assisted unicompartmental knee arthroplasty: data from a prospective, randomized controlled study. J Bone Joint Surg Am. 2016;98(8):627-35

14. Faour Martín O, Valverde García JA, Martín Ferrero MÁ, Vega Castrillo A, Zuil Acosta P, Suárez de Puga CC. The young patient and the medial unicompartmental knee replacement. Acta Orthop Belg. 2015;81(2):283-8.

15. Cavaignac E, Lafontan V, Reina N, Pailhé R, Wargny M, Laffosse JM, et al. Obesity has no adverse effect on the outcome of unicompartmental knee replacement at a minimum follow-up of seven years. Bone Joint J. 2013;95-B(8):1064-8.

16. Boissonneault $A$, Pandit $H$, Pegg $E$, et al. No difference in survivorship after unicompartmental knee arthroplasty with or without an intact anterior cruciate ligament. Knee Surg Sports Traumatol Arthrosc. 2013;21(11):2480-6.

17. Tinius M, Hepp P, Becker R. Combined unicompartmental knee arthroplasty and anterior cruciate ligament reconstruction. Knee Surg Sports Traumatol Arthrosc. 2012;20(1):81-7.

18. Weston-Simons JS, Pandit H, Jenkins C, Jackson WF, Price AJ, Gill HS, et al Outcome of combined unicompartmental knee replacement and combined or sequential anterior cruciate ligament reconstruction: a study of 52 cases with mean follow-up of five years. J Bone Joint Surg Br. 2012;94-B(9):1216-20. 